\title{
"Influence of Self-Efficacy, and Perceived Ease Of Use, Perceived Usefulness Behavioral Intention To Purchase Online In Tokopedia With Perceived Risk, As Variable Mediation (Studies in Society Padang)"
}

\author{
${ }^{1}$ Rosa Merry Yusvita, ${ }^{2}$ Vera Pujani \\ ${ }^{1}$ Students of Master of Management, Faculty of Economics, University of Andalas \\ e-mail: rosamerryyusvita@gmail.com \\ ${ }^{2}$ Lecturer at the Faculty of Economics, University of Andalas \\ e-mail: verapujani @ gmail.com
}

\begin{abstract}
This study aims to determine the effect of self-efficacy, and Perceived Ease of Use, Perceived Usefulness Against Behavioral Intention in TOKOPEDIA Online Purchase Transactions with Perceived Risk, as a mediating variable (Study in Padang City Communities) ". This research is explanatory with quantitative methods. The sampling technique used in this study was purposive sampling for customers who had shopped at the Tokopedia site, with a sample of 135 respondents. this research uses Partial Least Square with SmartPLS 3.0 program. The Results Showed that Self -efficacy, Perceived Ease of Use, Perceived Usefulness TOKOPEDIA Against Behavioral Intention in Online Purchase Transactions with Perceived Risk, as a mediating variable Self-efficacy Selfefficacy influences behavior towards positivity and significance,then Perceived Ease of Use Perceived Risk, as a mediating variable The implication of this research is to Increase Self-efficacy, Perceived Ease of Use, Perceived Usefulness will Increase Online TOKOPEDIA Behavioral Intention on Purchase Transactions with Perceived Risk, as a mediating variable
\end{abstract}

Keywords : Self-efficacy, Perceived Ease of Use, Perceived Usefulness Behavioral Intention

\section{PRELIMINARY}

One company that is the largest e-commerce in Indonesia is Tokopedia. Tokopedia is selling the online based company in Indonesia. Since formally launched Tokopedia managed to become one company based online purchase growing so rapidly. Data from iPrice (2019) map competition top ten ecommerce Indonesia based on the average number of visitors per month, ranking applications (AppStore and PlayStore) and population in social media. 


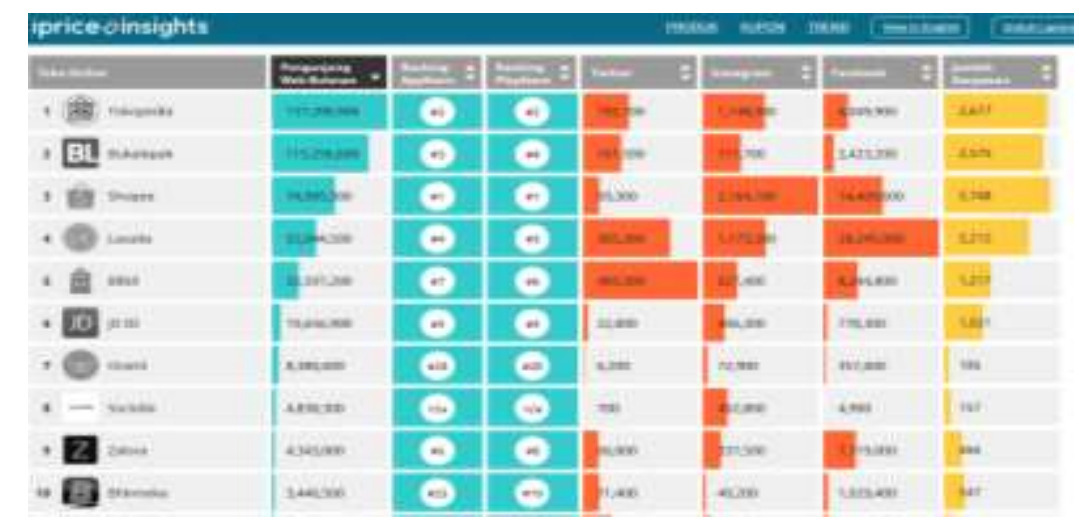

Figure 1.1

The competitive landscape the top ten e-commerce Indonesia Source: Survey IPrice 2019

TokopediaFirst positions ecommerce websites that are frequented by the data iPricequartal 12019 beat Lazada and Blibli. Shopee and other ecommerce Tokopedia an e-commerce company based in Indonesia and selling online. In building the security, convenience and consumer confidence this Tokopedia collaborated with 13 national logistics companies, from Pos Indonesia, JNE, TIKI, until the Go-GoJek Send. Even the latest innovation from Tokopedia itself for sellers who are in the same location as the buyer no shuttle service on the same day. Traders also do not need to start to build a logistics network, because they live to integrate into the store with the Tokopedia network. "Because of only $36 \%$ of adults who already have an account,

By carrying out the business model and the mall online marketplace, Tokopedia allows individuals, small shops and brands to open and manage online stores. Since its launch until the end of 2015, Tokopedia's basic services can be used by everyone for free.Tokopedia.com officially launched to the public on 17 August 2009 under the auspices of PT. Tokopedia founded by William Tanuwijaya and Leontinus Edison on February 6, 2009. PT Tokopediaget seed funding (initial funding) from PT IndonusaDwitama in 2009. Then in the following years, Tokopedia returned an injection of cash from global venture capitalists like East Ventures (2010), CyberAgent Ventures (2011), NetPrice (2012), and SoftBank Ventures Korea (2013). Then in October 2014, Tokopedia managed to make history as the first technology company in Southeast Asia, which received an investment of USD 100 million or Rp 1.2 trillion from Sequoia Capital and SoftBank Internet and Media Inc. (SIMI). On April 2016,

Among the results of existing research about online shopping, there is one variable that is interesting to study. These variables are self-efficacy, selfefficacy is something that is felt illustrates the trust that consumers in using innovation (Koksal, 2016). It can also be described as an assessment of a person's ability to use certain technologies to perform certain tasks (Venkatesh et al., 2003). Self-efficacy is rooted in the Social Cognitive Theory (SCT) by Bandura (1986). According to Davis (1989), perception self-efficacy similar to that perceived usefulness. However, Gu et al. (2009) showed that self-efficacy perception is antecedent to perceived ease of use Ecomers

Among the results of existing research on shopping online, there is one 
variable that is interesting to study. The variable is the perceived risk. The concept of perceived risk is defined as the risk arising from the uncertainty and consumers' perception of the consequences of the loss that will be suffered on the purchase of a product (Lee, 2016). Consumer perceptions of risk also affect business buying and selling on the internet. Consumers' ability to anticipate the risk that they will be receiving can increase customer satisfaction with the goods to be bought and the shopping experience on the Internet (Lee, 2016). Given the scene of the online transaction is in the virtual world, the element of uncertainty is very high. Traded goods also is virtual, meaning that the goods are only presented in the form of better information

Habitual consumers in receiving Internet technology has previously been described by Davis (1989) in his research on a person's behavior in accepting technological developments. According to Davis (1989), two things affect a person in receiving and using technological developments, ie the perception of ease (perceived ease of use), and perceptions of benefits (perceived usefulness). If a technology is considered easy to use and can provide benefits that a person tends to be keen to accept and use these technologies. Similarly, the use of the Internet as a medium for shopping, consumers now tend to be interested in shopping via the internet if they are shopping in an online ticket site or that is easy to learn and use,

Fenoumena is supported by some of the results of research on the factors that influence consumer behavior Indonesia to purchase on-site ecommerce sites that mention that some of the factors that influence consumers to shop online is their perception of internet technologies such as perceived ease (perceived ease of use), and perceptions of benefits (perceived usefulness).
Research conducted by Dimas, et al (2015) regarding the factors that influence consumers to shop at one of the e-commerce in Indonesia, namely OLX.CO.ID states that perceived ease of use (perceived ease of use), and perceptions of benefits (perceived usefulness ) into factors that influence consumer behavior in shopping at the online site.

Based on the background, while the objectives of this research are: 1.how to influence Self-efficacy to perceived Risk Online Purchase Transaction Tokopedia (Studies in Society Padang) 2. How Self-efficacy influences on Behavioral Intention Online Purchase Transaction Tokopedia (Studies in Society Padang) 3. How does the influence of Perceived Ease Of Use against, Perceived Risk in Online Purchase Transactions Tokopedia (Studies in Society Padang) 4. How does the influence of Perceived Ease Of Use againstbehavioralintentionOnline

Purchase Transaction TOKOPEDIA (Studies in Society Padang) 5. How does the influence of the Perceived Risk Perceived Usefulness No Purchase Online Tokopedia(Studies in Society Padang) 6. How Perceived Usefulness influence on behavioral IntentionOnline Store Purchase Transaction Pedia (Studies in Society Padang)7. How does the influence of Perceived Risk on behavioral IntentionOnline Purchase Transaction Tokopedia (Studies in Society Padang) 5. How Self-efficacy influences on Behavioral Intention Online Purchase Transaction Tokopedia with perceived Riskas mediation (Studies in Society Padang) 6. How does the influence of Perceived Ease Of Use Behavioral Intention to Purchase Transaction Online Tokopedia with perceived Riskas mediation (Studies in Society Padang)7. How Perceived Usefulness influence on Behavioral Intention Online Purchase Transaction Tokopedia with perceived Risk as mediation (Studies in Society Padang) 


\section{STUDY LITERATURE AND HYPOTHESES}

\section{Behavioral Intentions}

According to Olson and Peter (2012), Behavioral Intentions is a proposition that relates to the impending action. So it can be said that behavioral Intentions comes after consumer perceives a service or product offered. behavioral Intentions deemed to include a return visit and recommendation (Han and Ryu, 2010) you can predict future consumer behavior and consumer intentions to recommend.

PeScan has also been included in the behavioral component of attitude Intentions, if positive, it can generate customer loyalty(Han and Ryu, 2010), When the beneficial behavioral component, which is the purpose of the service provider, the customer positively affirm their chances to re-visit the provider and then spread positive review to others with whom they are associated.

\section{Qin and Prybotuk (2010) in research related to behavioral Intentionsuse indicators to predict behavioral Intentions, as follows: \\ 1. Recommendation. \\ 2. Intention to eat at the same place. \\ 3. Say good things about the venue. \\ 4. Buy more}

\section{Self Efficacy}

perceived self-efficacy illustrates the trust that consumers in using innovation (Koksal, 2016). It can also be described as an assessment of a person's ability to use certain technologies to perform certain tasks (Venkatesh et al., 2003). Self-efficacy is rooted in the Social Cognitive Theory (SCT) by Bandura (1986). According to Davis (1989), the perception of selfefficacy similar to that perceived usefulness. However, Gu et al. (2009) showed that self-efficacy perception is antecedent to perceived ease of use
Ecomers

Greogory (2011) defines Self Efficacy as confidence to know that their ability to perform some form of control over one's own benefit and events in environmental surroundings. According Ormrod (2008) Self-efficacy is the belief that one is capable of running a certain behavior to achieve certain goals. An important issue regarding the concept of self-efficacy and self-efficacy measurement was the specific nature, special accordance with the field situation, or particular circumstances.

According Kulviwat et al (2016) indicators used to measure the variables Perceived Self Efficacy are:

1. using Alone

2. Have time to mengunakanya

3. Having knowledge

4. Having skills

\section{Perceived Risk}

According to Koenig-Lewis et al. (2010), the perceived risk associated with the probability that something will happen and the consequences of the results is usually undesirable when it occurs. The vagueness of mobile banking services, the main features of the other services, causing hardship to the customers in the evaluation of the service before consumption. Thus, consumers tend to worry about security issues. For example, customers are concerned about the possibility that their money or personal information may be transferred to other parties without consent when transacting via E-Commerce Technology (Hanafizadeh et al., 2014; Ramdhony\&Munien, 2013). IDT also incorporates the perceived risk as a factor affecting the use of new technologies.

Schiffmann and Kanuk (2015) define the perceived risk as to the uncertainty faced by consumers when consumers can not foresee or predict the consequences of a decision to buy a product. The concept of perceived risk is defined as the risk arising from the 
uncertainty and consumers' perception of the consequences of the loss that will be suffered on the purchase of a product (Downling \&Staeling, 2014).

According to Masoud (2013) Dimensions contained in the perceived risk of which is

\section{Financial risk,}

Financial risk translated as the potential loss, including consumer inconvenience by the use of credit cards online that proved to be the major barrier to online shopping (Maignan and Lukas, 2014).

2. product risk

product risk is a view towards the purchase of products that may not match the desire and loss that occurs when a product does not achieve the expected performance (Kim et al., 2012).

3. time risk

time risk is the view that time, comfort or effort may be wasted when the purchased product repaired or replaced (Hanjun et al., 2014). Time risk including the occurrence of discomfort when shopping online, often also results in difficulty navigating forms and submit orders or products that will be accepted pending (Forsythe et al., 2006).

4. delivery risk

The potential loss of productrelated shipment is lost, damaged products and products that misdirected (Dan et al., 2017).

5.Social risk

Referring to the perception that the product purchased is not approved by family and friends ( $\mathrm{Li}$ \& Zhang, 2012).

6.Information security risk Consumers can learn about the value of products through the site's features such as quality of product information, transaction and delivery capabilities, and quality of service efficiency; However, if there is no mechanism attached to information security, online shopping intention will be affected. Information security factor can be used depending on the capabilities of the Internet retailers to meet consumer expectations in a virtual environment online shopping (Chang \& Chen, 2012).

\section{Perceived Usefulness}

Perceived Usefulness defined as the extent to which a person believes that using a particular system would enhance his job performance. The main reason people exploit the internet banking system is that they find the system useful for their banking transactions (Sentosa et al., 2012).

Davis (1989), perceived ease of use of technology is defined as a measure in which a person believes that the computer can be easily understood and used. This definition is also supported by Wibowo (2006) which states that the perception of the ease of use of technology is defined as a measure in which a person believes that the technology can be easily understood and used. Davis et al. (1989) and Davis (1993) define the perceived ease of use as a measure of where the user in future assume a barrier-free system. Davis (1989) mentions the indicators used to measure the perceived ease of use that is easy to learn, flexible, able to control the work, and easy to use.

According Kulviwat et al (2016) indicators used to measure variables Perceived usefullness is:

1. help to be more effective

2. help being lebihefektif

3. save me time to use it

4. the fewest steps to accomplish what you want 
5. making the task easier to accomplish

\section{Perceived Ease of Use}

Persepsi ease (perceived ease 088 use) is a person's belief in the use of a technology which can be easily used and understood, research previously shown that the perceived ease of positive influence on the attitude of the use of technology.

empirical studies of Al-Somali et al. (2008) who took the subject of research in Saudi Arabia, showed that the perceived ease of influencing attitudes Tokopedia E-commerce users. The sample used in this study is the community Saudi Arabia randomly selected.

Perception individuals with regard to ease of use of a computer (perceived ease of use) is the degree to which an individual believes that using a particular system would be free of errors. This perception then will have an impact on behavior, ie the higher one's perception of the ease of use of the system, the higher the level of utilization of information technology (Nizaruddin, 2014).

Perceived Ease Of Usedefined as a level of trust people that use technology will bring them free from mental and physical effort (Gardner and Amoroso, 2004).

According Kulviwat et al (2016) indicators used to measure variables Perceived Ease of Use are:

1. Easy to use

2. learn to use it quickly

3. easy to remember how to use

4. Easy to learn to use.

Research done by Alawan et al (2016) found that highly affects the Self Efficacy Perceived Risk, Then strengthened by a study done by Sentosa et al (2016) and Reinforced By a study to be done Runiar Yang (2016) found similar results
$\mathrm{H1}$ : Self-efficacy influence on perceived Risk Online Store Purchase Transaction Pedia (Studies in Society Padang)

Greogory (2011) defines Self Efficacy as the confidence to know that their ability to perform some form of control over one's own benefit and events in the surrounding environment. According to Ormrod (2008) Self-efficacy is the belief that one is capable of running a certain behavior to achieve certain goals. An important issue regarding the concept of self-efficacy and self-efficacy measurement was the specific nature, special accordance with the field situation, or particular circumstances. Research done by Alawan et al (2016) found that highly affects the Self EfficacyBehavioral Intention, then strengthened by a study done by Sentosa et al (2016) and Reinforced By a study to be done Runiar Yang (2016) found similar results

H2: Self-efficacy influence on behavioral Intention Online Purchase Transaction TOKOPEDIA (Studies in Society Padang)

Results of research conducted by Alalwa et al. (2016) showed that behavioral intentions (behavioral intention) are strongly influenced by the perceived usefulness, perceived ease of use, and perceived risk. Similarly, in the context of an online shopping system, if the user thinks that the system is useful, then they are more likely to accept it. Therefore, according to TAM, it was hypothesized that Public Works will have a significant positive effect on the Adoption of e-commerce users. According to TAM, the direct effect of PEOU and PU explained by an increase in PEOU, which results in improved performance by storing the effort required to do the same job.

Sharma et al. (2015) tested the model of neural network that is capable 
of analyzing all the independent variables, such as Perceived Risk, trust, perceived usefulness, perceived ease of use, attitude and variable other demographics, while perceived ease of use and variable other demographics were not significant predictors of adoption of E-commerce Cheng (2014) states that the perceived usefulness (PU), perceived ease of use (PEOU), perceived enjoyment (PE), and compatibility play an important role in influencing the learners' intention to use m-learning. private innovation can moderate the effects of PU, PEOU, and compatibility on the intention to use $\mathrm{m}$ learning except for PE effect on the intention to use m-learning.

H3: Perceived Ease of Use effect on Perceived Risk in Online Purchase Transactions TOKOPEDIA (Studies in Society Padang

Rauniar (2014) examined the behavior of individual adoption in using social networking site Facebook. Influence on the intention to use social networks based on perceived ease of use (EU), the user's critical mass (CM), a social networking site capability (CP), perceived playfulness (PP), trustworthiness (TW), and perceived usefulness (PU) tested from 398 users of Facebook were collected from a webbased questionnaire survey. The results show that the social media TAM revised model proposed in this study supports the hypothesis of all social media usage behavior. These results provide evidence for the importance of the key variables in addition to TAM in considering user engagement on social media sites and other business strategies related to social media to increase profits. Research conducted by Jamshidi \& Hussin (2016) concluded that religiosity in the TAM model thereby increasing the intention to use. Meanwhile, perceived usefulness, perceived ease of use and attitude explains the low level of variance regarding the intention to use (intention to use), by adding perceived religiosity in the TAM model, this construction contributes to an increase in the variance.

$\mathrm{H} 4$ : Perceived Ease of Use affect the Behavioral Intention Online Purchase Transaction Tokopedia (Studies in Society Padang

Mansour (2016) suggested that positive messages Perceived Usefulness has an influence on the Perceived Risk) Before reaching a purchase decision, consumers must go through several stages of Perceived Usefulness is defined as the extent to which a person believes that using a particular system would enhance or her job performance. The main reason people exploit Tokopedia E-commerce systems is that they find a useful systems for their transactions (Sentosa et al., 2012).

H5: Perceived usefulness effect on Perceived Risk in Online Purchase Transactions Tokopedia (Studies in Society Padang

Rauniar (2014) examined the behavior of individual adoption in using social networking site Facebook. Influence on the intention to use social networks based on perceived ease of use (EU), the user's critical mass (CM), a social networking site capability (CP), perceived playfulness (PP), trustworthiness (TW), and perceived usefulness (PU) tested from 398 users of Facebook were collected from a webbased questionnaire survey. The results show that the social media TAM revised model proposed in this study support the hypothesis of all social media usage behavior. These results provide evidence for the importance of the key variables in addition to TAM in considering user engagement on social media sites and other business strategies related to social media to increase profits. Research conducted by Jamshidi \& Hussin (2016) concluded that religiosity in the TAM model thereby increasing the 
intention to use. Meanwhile, perceived usefulness, perceived ease of use and attitude explains the low level of variance regarding the intention to use (intention to use), by adding perceived religiosity in the TAM model, this construction contributes to an increase in the variance.

H6: Perceived usefulness effect on Behavioral Intention Online Purchase Transaction Tokopedia (Studies in Society Padang

According to Koenig-Lewis et al. (2010), the perceived risk associated with the probability that something will happen and the consequences of the results is usually undesirable when it occurs. The vagueness of mobile banking services, the main features of the other services, causing hardship to the customers in the evaluation of the service prior to consumption. Thus, consumers tend to worry about security issues. For example, customers are concerned about the possibility that their money or personal information may be transferred to other parties without consent when transacting via ECommerce Technology (Hanafizadeh et al., 2014; Ramdhony\&Munien, 2013). IDT also incorporate the perceived risk as a factor affecting the use of new technologies.

H7: perceived Risk effect on Behavioral Intention Online Purchase Transaction Tokopedia (Studies in Society Padang

Research done by Alawan et al (2016) found that Perceived Risk as a mediating variable in speaking about the relationship Self Efficacy against Behavioral Intention, then strengthened by a study done by Sentosa et al (2016) and Reinforced By a study to be done Runiar Yang (2016) found similar results H8: Self-efficacy influence on

Behavioral Intention to Perceived Risk as mediation Online Purchase Transaction TOKOPEDIA (Studies in Society Padang)

Research done by Alawan et al (2016) found that Perceived Risk as a mediating variable in speaking about the relationship Perceived Ease of Use to Behavioral Intention, then strengthened by a study done by Sentosa et al (2016) and Reinforced By a study to be done Runiar Yang (2016) found similar results Perceived ease (perceived ease of use) is a person's belief in the use of a technology which can be easily used and understood. Several previous studies have shown that the perceived ease of positive influence on the attitude of the use of technology.

H9: Perceived Ease of Use influence on Behavioral Intention Online Purchase Transaction Tokopedia with Perceived Risk as mediation (Studies in Society Padang)

Mansour (2016) suggested that the two dimensions of trust, namely the integrity and credibility have influence positive messages against perceived benefits (perceived usefulness) and exert both directly and provide a direct positive effect on the attitude (attitude) towards adoption of Internet banking and behavioral intentions (behavioral intention), Therefore, the importance of increasing the perceived usefulness in improving the attitude in the use of technology.

H10: Perceived usefullness effect on Behavioral Intention to Perceived Risk as mediation Online Purchase Transaction Tokopedia (Studies in Society Padang)

Based on existing studies, the framework in this study are as follows: 


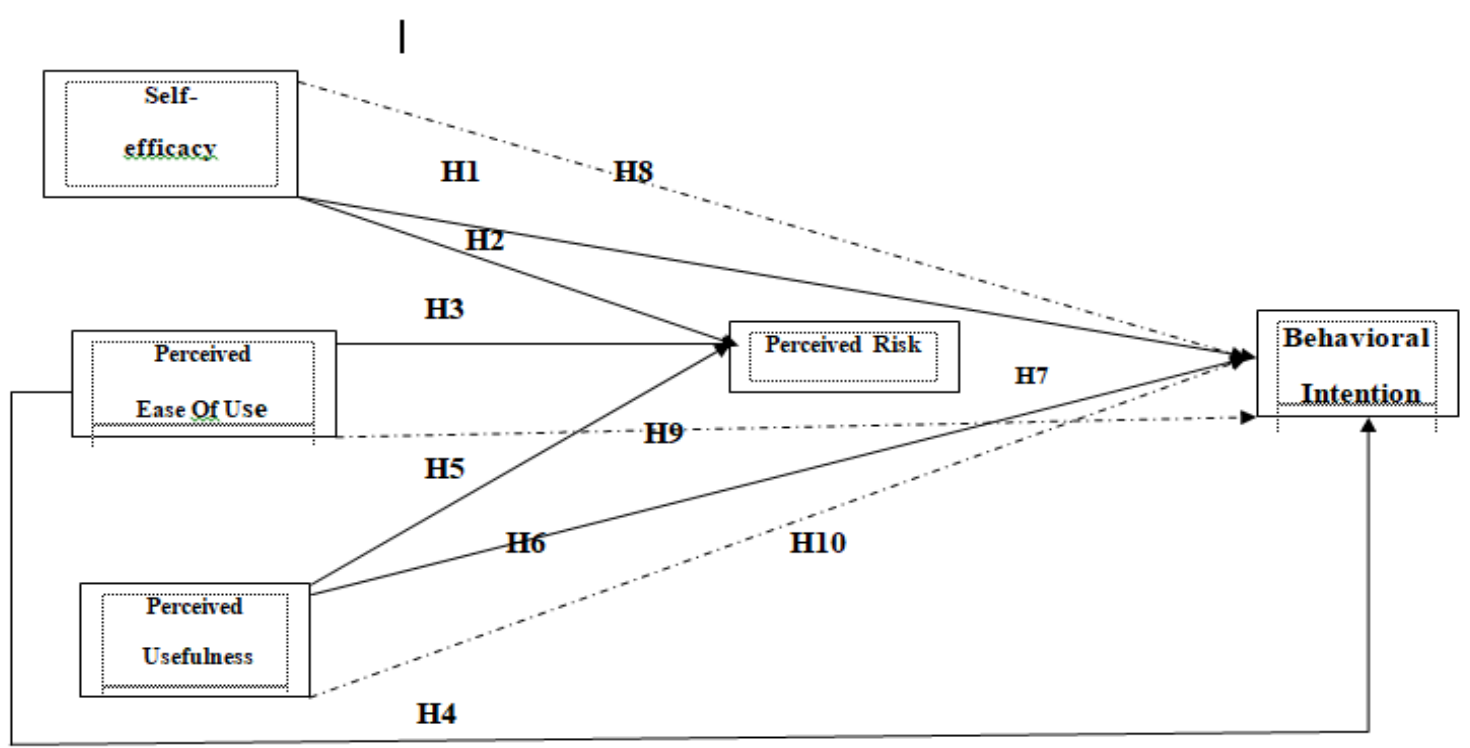

Figure 2 Model Theoretical Framework Research

\section{RESEARCH METHODS Population and Sample}

The population in this study is The people of Padang who transact using online Tokopedia The number of samples set out in this study was 135 respondents. The sampling technique used in this research is purposive sampling. Definition of purposive sampling according sekaran (2011) is a technique used to take samples with special consideration they deserve for the research sample. The sample selection criteria are:

Data collection technique

The data collection techniques used in this study is the documentation and questionnaires.

a. Documentation, which collects data through files or reports related to the problems examined so that it can be used in research (have now, 2011). Data collection through the documentation in this study was obtained from reports issued by the relevant parties and can be used as the data in the study.

b. The questionnaire, questionnaires are structured techniques used to collect data that consists of a series of questions, written or oral, to respond to the answer (Malhotra, 2009).

\section{Analysis Method}

Based on the hypothesis, a tool used for data analysis in this research is to use software SmartPLS 3.0 starting from the measurement model (outer model), structural model (inner model), and testing hipotesis.Sedangkan to test the mediating effect used methods of variance accounted for (VAF) and bootstrapping in the distribution of indirect influence because they were considered more appropriate because it does not require any assumptions about the distribution of variables. To calculate the VAF can use the formula (Hair et al., 2010) as follows:
If the value of VAF above $80 \%$ then it shows the role of $M$ as a full pemediasi (full mediation). M categorized indirect influence

as partial pemediasi if VAF values ranged from $20 \%$ to $80 \%$, but if $\mathrm{VAF}$ is less than $20 \%$ can be concluded that almost no mediating effect. 
variable Operations

The variables used in this study are as follows:

1. Dependent Variables:

a. behavioral Intention $(\mathrm{Y})$

2. Independent variables
a. Self-efficacy (X1)
b. Perceived Ease Of Use (X2)
c. Perceived Usefulness (X3)

3. variable Mediation a. perceived Risk (M)

\section{RESULTS AND DISCUSSION}

\section{characteristics of Respondents}

As for the characteristics of the respondents in this study were gender, age, education, past, monthly income, shopping frequency, and the types of products purchased on the site ever Shopee.

Table 1.

Characteristics of Respondents

\begin{tabular}{lcc}
\hline Characteristics & F & P \\
\hline Gender & 42 & 31.1 \\
Male & 93 & 68.9 \\
Woman & & \\
Age & 17 & 12.6 \\
under 20 years & 81 & 60.0 \\
21 to 35 years & 37 & 27.4 \\
36 to 50 years & & \\
Gender & 7 & 5.2 \\
PNS / TNI / Police & 6 & 4.4 \\
Employees BUMN / & 49 & 36.3 \\
College student & 57 & 42.2 \\
Employers / Self Employed & 16 & 11.9 \\
General employees & & \\
Allowance / Income & 21 & 15.6 \\
RP 2,000,000 S / D RP 3,999,000 & 93 & 68.9 \\
RP 4,000,000 S / D RP 5.999 million & 21 & 15.6 \\
Above RP 6,000,000 & & \\
Last education & 35 & 25.9 \\
\hline High School Graduate / equivalent & 14 & 10.4 \\
Diploma & 86 & 63.7 \\
Bachelor degree & & \\
Marital status & 55 & 40.7 \\
Single & 79 & 58.5 \\
Married & & .7 \\
Widow widower & &
\end{tabular}

By sex is known that the majority of respondents who participated in this study based on gender is female with a number of 93 respondents (68.90\%). While the remaining 42 respondents
$(31.10 \%)$ were male. These data indicate that the most frequent customers shop on the site pedia shop in Padang are women. 
Based on the age it can be concluded that the respondents who shopped at Tokopedia site with an age range from 21 to 35 years that is equal to $60 \%$, and followed by the customer with an age range of 36 to 50 years at $27.4 \%$. This indicates that customers in KotTokopediaa Padang are in the age range 21-35 years, which can be categorized age range of young age.

most respondents characteristics based on the work that is an entrepreneur / self-employed as much $42.2 \%$ Or about 57 While the fewest respondents who work as PNS / TNI / Police

Composition distribution among respondents with a background of money income per month. Results showed that respondents predominantly have an income of incomeUntilRp 3,000,000 Rp 5.999 million, -as much as $68.9 \%$. Respondents then the smallest is underRp 2.000.000, -

Based Education level results show that respondents have a level of education dominated S1as much 83 and $63.7 \%$ Accompanied by respondents high school graduates 35 and 25.9\% among respondents with a composition distribution background Marital Status. The results show that respondents have dominated Marital Status. Marriedas much 79 and $58.5 \%$ Of respondents who have not been accompanied by married by 55 and $40.7 \%$

\section{Data analysis}

\section{Measurement Model (Outer Model)}

1. convergent Validity

The data have been obtained from online questionnaires should be tested for validity and reliability. The research data were considered valid if the instrument used in the study were appropriate and can work according to its function. Convergent validity of the measurement model with reflective indicators assessed based on the correlation between the item score / component score is calculated by SmartPLS 3.0. The size of individual reflective said to be high if more than 0.70 correlated with the construct to be measured. However, to study the early stages of development measurement scale loading value 0.50 to 0.60 are considered sufficient (Ghozali, 2014). Loading value of each indicator variables of the study are shown in Table 2 .

Table 2. Outer Loadings

table 4.11

Outer Loadings

\begin{tabular}{|l|r|r|r|l|l|}
\hline & $\begin{array}{c}\text { behavioral } \\
\text { Intentions }\end{array}$ & $\begin{array}{c}\text { Perceived } \\
\text { Ease of } \\
\text { Use }\end{array}$ & $\begin{array}{c}\text { perceived } \\
\text { Risk }\end{array}$ & $\begin{array}{c}\text { perceived } \\
\text { Usefulness }\end{array}$ & $\begin{array}{c}\text { self } \\
\text { Efficacy }\end{array}$ \\
\hline BI1 & 0661 & & & & \\
\hline BI2 & 0834 & & & & \\
\hline BI3 & 0880 & & & & \\
\hline B14 & 0752 & & & & \\
\hline PE1 & & 0773 & & & \\
\hline PE2 & & 0805 & & & \\
\hline PE3 & & 0719 & & & \\
\hline PE4 & & 0816 & & & \\
\hline PR1 & & & 0752 & & \\
\hline PR2 & & & 0739 & & \\
\hline PR3 & & & 0813 & & \\
\hline PR4 & & & 0772 & & \\
\hline PU1 & & & & 0805 & \\
\hline
\end{tabular}


ISSN 1412-2936

EISSN 2549-7308

\begin{tabular}{|l|l|r|r|r|r|}
\hline & $\begin{array}{c}\text { behavioral } \\
\text { Intentions }\end{array}$ & $\begin{array}{c}\text { Perceived } \\
\text { Ease of } \\
\text { Use }\end{array}$ & $\begin{array}{c}\text { perceived } \\
\text { Risk }\end{array}$ & $\begin{array}{c}\text { perceived } \\
\text { Usefulness }\end{array}$ & $\begin{array}{c}\text { self } \\
\text { Efficacy }\end{array}$ \\
\hline PU2 & & & & 0794 & \\
\hline pu3 & & & & 0614 & \\
\hline PU4 & & & & 0717 & \\
\hline PU5 & & & & 0677 & \\
\hline SE1 & & & & & 0740 \\
\hline SE3 & & & & & 0795 \\
\hline SE4 & & & & & 0805 \\
\hline
\end{tabular}

Source: Primary Data Olah with SmartPLS 3.0 (2019

Based on the results of the data analysis found that the indicators of each study variable can be valid, because it has met convergent validity, where the value of the loading of the research instrument> 0.60 . This indicates that each instrument of the research variables are appropriate and can work according to its function.
2. composite Reliability

Test reliability can be measured by two criteria: reliability and Cronbach alpha compositing. A variable is said to be reliable if the value dancronbach alpha composite reliability above 0.70 . And is said to be reliable if the value of variable $\mathrm{ST}>0.5$.

\begin{tabular}{|l|r|}
\hline & $\begin{array}{c}\text { Cronbach's } \\
\text { Alpha }\end{array}$ \\
\hline behavioral Intentions & 0790 \\
\hline Perceived Ease of Use & 0788 \\
\hline perceived Risk & 0771 \\
\hline perceived Usefulness & 0745 \\
\hline self Efficacy & 0785 \\
\hline
\end{tabular}

Based on the results of data analysis can be concluded that all the variables in the study of composite reliability reliable because the value of each variable dancronbach alpha> 0.70 . In addition the value of AVE each variable $>0.5$.

\section{Structural Model (Inner Model)}

\begin{tabular}{|c|r|r|}
\hline $0 \_A$ & $\begin{array}{c}\text { composite } \\
\text { Reliability }\end{array}$ & $\begin{array}{c}\text { Average Variance } \\
\text { Extracted (AVE) }\end{array}$ \\
\hline 0809 & 0865 & 0618 \\
0803 & 0861 & 0608 \\
\hline 0774 & 0853 & 0592 \\
\hline 0761 & 0832 & 0503 \\
\hline 0782 & 0824 & 0609 \\
\hline
\end{tabular}
value of $R$-square is a goodness of fit test. Assessment models with PLS begins to see R-square values for each dependent variable. R-square value changes can be used to see the effect of the independent variable on the dependent variable, does have a substantive effect.

table 3

Test Goodness of Fit - Inner Model (Structur Model

\begin{tabular}{|c|c|c|}
\hline & R Square & R Square Adjusted \\
\hline behavioral Intentions & 0737 & 0729 \\
\hline perceived Risk & 0466 & 0454 \\
\hline
\end{tabular}

table 3 shows the R-square value for the variable Behavioral Intentions is 0.737 , meaning Behavioral Intentions influenced by self-efficacy, Perceived Ease Of Use, Perceived Usefulness Perceived Risk 0.737 atau $73.7 \%$, while the remaining 
$26.3 \%$ is influenced by other factors. And the R-square value of the variable Perceived Risk is0466, Meaning that self-efficacy, Perceived Ease Of Use, Perceived Usefulness Perceived Risk affecting $46.6 \%$ while the remaining $53.4 \%$ is influenced by other factors. The higher the R-square value, the greater the ability of independent variables in explaining the independent variable so that a structural equation, the better.

\section{Hypothesis test}

For testing of the hypothesis, it can be done using bootstrapping function in SmartPLS 3.0.untuk accept or reject the hypothesis can be made by looking at the value of the probability and the $t-$ statistic. The hypothesis will be accepted if the value of t-statistic $>$ t-table (1.96), and $p$-value $<0.05$.

\begin{tabular}{|l|c|c|c|c|c|}
\hline & $\begin{array}{c}\text { Original } \\
\text { Sample (O) }\end{array}$ & $\begin{array}{c}\text { Sample } \\
\text { Mean } \\
(\mathbf{M})\end{array}$ & $\begin{array}{c}\text { Standar } \\
\mathbf{d} \\
\text { Deviatio } \\
\mathbf{n} \\
(\mathbf{S T D E V})\end{array}$ & $\begin{array}{c}\text { T Statistics } \\
(\mathbf{O} / \\
\text { STDEV } \mid \text { |) }\end{array}$ & $\begin{array}{c}\mathbf{P} \\
\text { Values }\end{array}$ \\
\hline $\begin{array}{l}\text { Self Efficacy -> Behavioral } \\
\text { Intentions }\end{array}$ & 0173 & 0172 & 0064 & 2,683 & 0008 \\
\hline Self Efficacy -> Perceived Risk & 0121 & 0114 & 0070 & 2,718 & 0008 \\
\hline $\begin{array}{l}\text { Perceived Ease of Use -> } \\
\text { Behavioral Intentions }\end{array}$ & 0048 & 0051 & 0081 & 2,599 & 0005 \\
\hline $\begin{array}{l}\text { Perceived Ease of Use -> } \\
\text { Perceived Risk }\end{array}$ & 0535 & 0533 & 0117 & 4,575 & 0000 \\
\hline $\begin{array}{l}\text { Perceived Usefulness -> } \\
\text { Behavioral Intentions }\end{array}$ & 0117 & 0414 & 0082 & 5084 & 0000 \\
\hline $\begin{array}{l}\text { Perceived Usefulness -> } \\
\text { Perceived Risk }\end{array}$ & 0194 & 0105 & 0131 & 2,916 & 0004 \\
\hline $\begin{array}{l}\text { Perceived Risk -> Behavioral } \\
\text { Intentions }\end{array}$ & 0379 & 0377 & 0066 & 5760 & 0000 \\
\hline
\end{tabular}

Table 4 shows the test of direct influence of the independent variables and the dependent variable. Based on the above table it can be concluded that:

1. Hypothesis 1 received variable self Efficacy effect on the Behavioral Intentions for the value of t-statistic $(2,683)>T$ table (1.96) and the p-value $(0,008)<0.05$

2. Hypothesis 2 received variable Self Efficacy variables affect the perceived risk because the value of t-statistic (2718)> t-table (1.96) and the $p$-value $(0.008)<0.05$.

3. Hypothesis 3 received variable Variables Perceived Ease of Use affect the Behavioral Intentions, because the value of t-statistic (2599)> t-table (1.96) and the $p$ value $(0.005)<0.05$.
4. Hypothesis 4 received variable Variables Perceived Ease of Use affect the Behavioral Intentions, because the value of t-statistic $(4,575)>$ T-table $(1.96)$ and the $p$ value $(0.000)<0.05$

5. Hypothesis 5 is accepted that the variable Perceived Usefulness variables affect the Behavioral Intentions, because the value of tstatistic (5084)> T-table (1.96) and the $p$-value $(0000)<0.05$.

6. Hypothesis 6 received variable Perceived Usefulness variables affect the perceived risk because the value of $t$-statistic $(2,916)>\mathrm{T}$ table (1.96) and the p-value $(0,004)<0.05$.

7. Hypothesis 7 received variable Variables, variables affect the Perceived Risk Behavioral Intentions, because the value of t- 
ISSN 1412-2936

EISSN 2549-7308

statistic $(5.760)>$ t-table $(1.96)$

and the p-value $(0.000)<0.05$

\section{Mediation Effect Test}

Mediation Self-Efficacy Test of the Behavioral Intention Through Perceived Risk

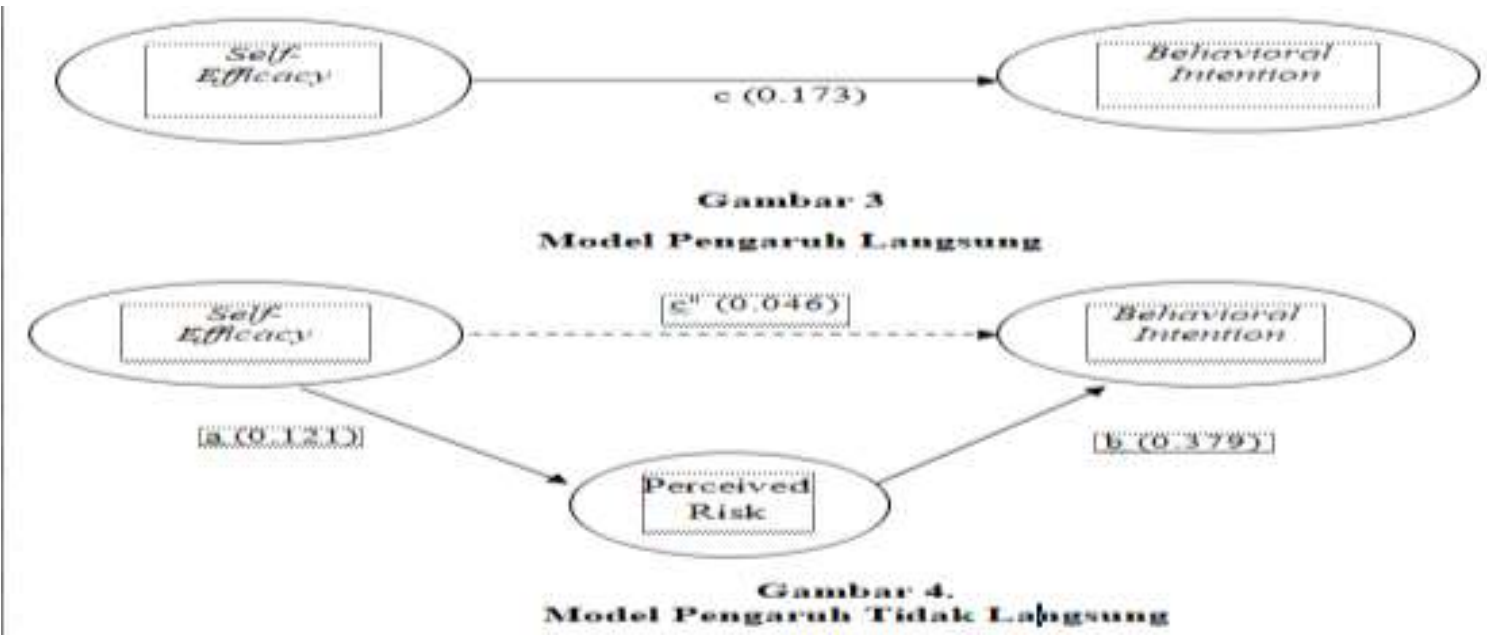

The following is an analysis of variance accounted for (VAF) mediation Self- Efficacy test against Intention Through Behavioral Risk Perceived as a mediating variable.

$$
\begin{gathered}
\mathrm{VAF}=\frac{\text { pengaruh tidak langsung }}{\text { pengaruh langsung }+ \text { pengaruh tidak langsung }} \\
\qquad \mathrm{VAF}=\frac{0.046}{0,173+0.046}=21.0 \%
\end{gathered}
$$

The above calculation shows the test results of variance accounted for (VAF) test variables mediation Mediation Self-Efficacy Test on Behavioral Intention Through Perceived Risk with $21: 00 \%$ value. These results show the level of mediation partially (partial) by category VAF $\leq 20 \% \leq 80 \%$. Therefore it can be concluded that the Perceived Risk partially mediate or part (partial mediation) the relationship between Self-Efficacy and Behavioral Intention

Mediation Perceived Ease Of Use of the Behavioral Intention Through Perceived Risk 


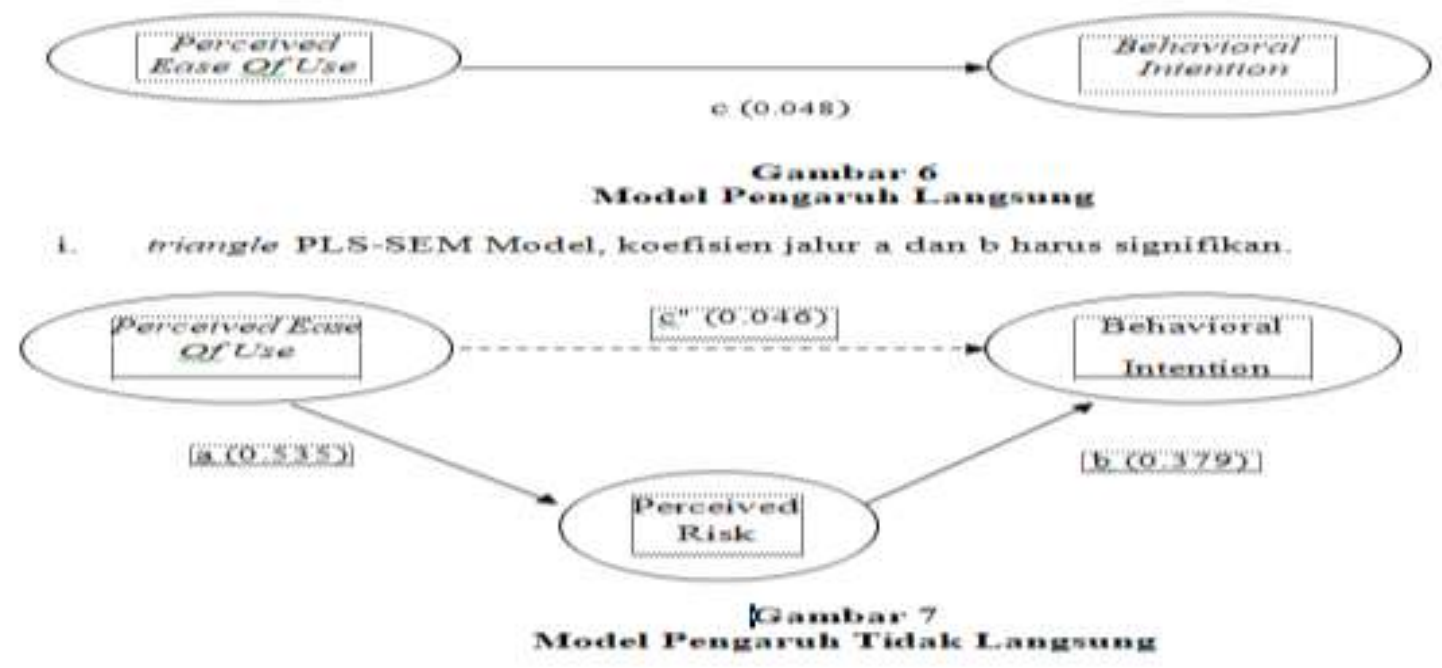

The following is an analysis of variance accounted for (VAF) test mediating variables Perceived Ease Of Use of the Behavioral Intentions through Perceived Risk as a mediating variable.

$$
\begin{gathered}
\mathrm{VAF}=\frac{\text { pengaruh tidak langsung }}{\text { pengaruh langsung }+ \text { pengaruh tidak langsung }} \\
\qquad \mathrm{VAF}=\frac{0.203}{0.048+0.203}=80.9 \%
\end{gathered}
$$

The above calculation shows the test results of variance accounted for (VAF) test variable Test mediation Mediation Perceived Ease Of Use of the Behavioral Intentions through Perceived Risk, with a value of $80.90 \%$. These results show the level of Mediation Full VAF category> $80 \%$. Therefore it can be concluded that the Perceived Risk Mediation mediates Full (Full Mediation relationship between

Perceived Ease Of Use of the Behavioral Intentions

\section{Mediation Test against Behavioral Intention Perceived Usefulness Perceived Risk Through}

The following is an analysis of variance accounted for (VAF) test mediating variables Perceived Ease Of Use of the Behavioral Intentions through Perceived Risk as a mediating variable.

$$
\begin{gathered}
\mathrm{VAF}=\frac{\text { pengaruh tidak langsung }}{\text { pengaruh langsung }+ \text { pengaruh tidak langsung }} \\
\qquad \mathrm{VAF}=\frac{0.203}{0.048+0.203}=80.9 \%
\end{gathered}
$$

The above calculation shows the test results of variance accounted for (VAF) test variable Test mediation Mediation Perceived Ease Of Use of the Behavioral Intentions through Perceived Risk, with a value of $80.90 \%$. These results show the level of Mediation Full VAF category> $80 \%$. Therefore it can be concluded that the Perceived Risk Mediation mediates
Full (Full Mediation relationship between Perceived Ease Of Use of the Behavioral Intentions 


\section{Mediation Test against Behavioral Perceived Risk Through}

Intention Perceived Usefulness

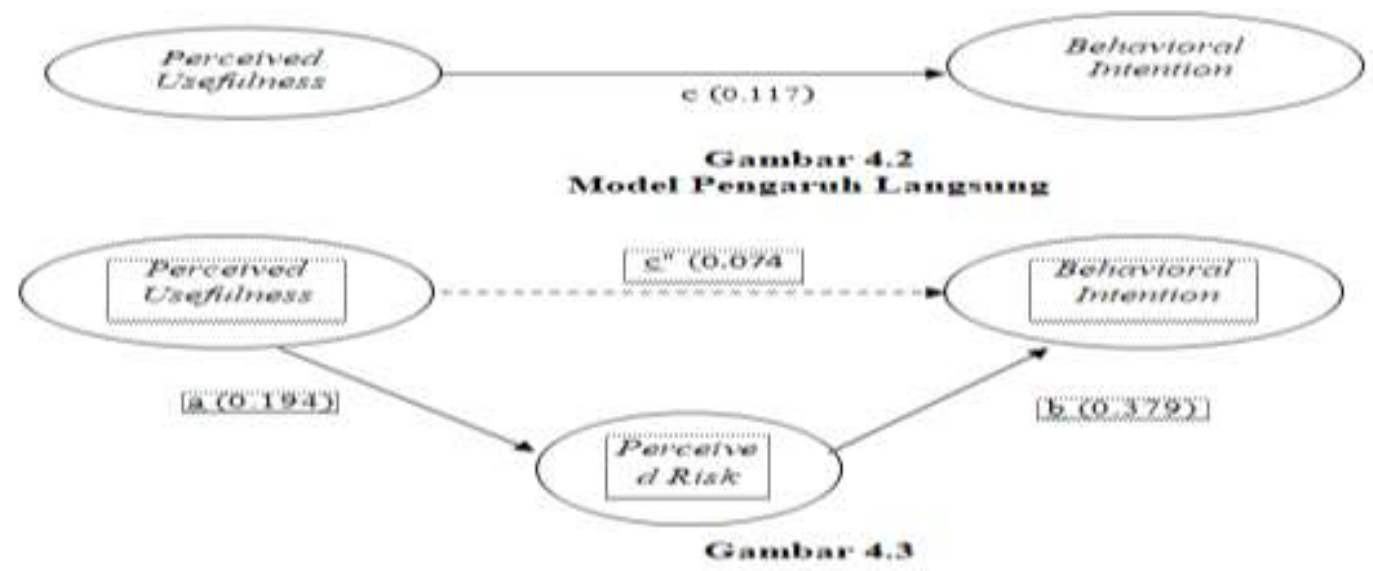

The following is an analysis of variance accounted for (VAF) test mediating variables Perceived Usefulness of the Behavioral Intentions through Perceived Risk as a mediating variable.

$$
\begin{gathered}
\mathrm{VAF}=\frac{\text { pengaruh tidak langsung }}{\text { pengaruh langsung }+ \text { pengaruh tidak langsung }} \\
\mathrm{VAF}=\frac{0.074}{0.117+0.074}=38.6 \%
\end{gathered}
$$

In determining the test mediation Perceived Usefulness of the Behavioral Intentions through Perceived Risk, it is necessary to mediation in the analysis procedure SEM VAF PLS method. Here is the analysis procedure of mediation by the method of VAF. The above calculation shows the test results of variance accounted for (VAF) test variable Test mediation Mediation Perceived Usefulness of the Behavioral Intentions through Perceived Risk, with a value of $38.6 \%$. These results show the level of Mediation Full category VAF VAF $\leq 20 \% \leq 80 \%$ Therefore, it can be concluded that the Perceived Risk Mediation Part or (partial mediation) the relationship between Perceived Usefulness of the Behavioral Intentions.

\section{Discussion}

\section{PenAgainst garuhperceived Risk \\ Self-efficacy}

The first hypothesis presented earlier Self-efficacytoperceived
RiskOnline Purchase Transaction TOKOPEDIA (Studies in Society PadangBased on the results of tests that have been conducted, one hypothesis is accepted. This is because the value oft $t-$ statistics (2718)> t-table (1.96) and the p-value $(0.008)<0.05$ That is, the better Self-efficacy consumer, Then the value of the perceived Riskcustomers will also be getting better. And vice versa. As well asTokopedia as one of the sites in Indonesia.Hal marketplace this can happen because the majority of respondents in this study were identical millennial generation close to the technological, including on-line shopping.

The results of this study are supported by a study done by Alawan et al (2016) found that Self Efficacy is very influential and significant to Perceived Risk, then strengthened by a study done by Sentosa et al (2016) and Reinforced By study to What do Runiar (2016) found similar results 
Against Self-efficacy influence
Behavioral Intention presented earlier Selfefficacytobehavioral Intention Online Purchase Transaction TOKOPEDIA (Studies in Society PadangBased on test results that have been done, the second hypothesis is accepted. This is because the value of t-statistic $(2,683)>$ T-table (1.96) and the p-value $(0,008)$ $<0.05$ That is, the better Self-efficacy consumer, The Behavioral Intention customer will also be getting better

According to the results of a large partially respondent data in use by the milieneal aged 21 to 35 so that the Selfefficacy is very good in influencing customer Behavioral Intention, thenTokopedia in use by the aged 36 to 50 years, in terms of procurement of technology is still lacking Self Efficacy must continue to improve so that consumers have confidence using the innovations of facilities Online owned by Tokopedia

\section{Effect of Perceived Ease of Use Against Perceived Risk}

The third hypothesis presented earlier Perceived Ease of Use Against Perceived Risk Online Purchase Transaction TOKOPEDIA (Studies in Society PadangBased on the results of testing that has been done, hypothesis 3 is accepted. This is because the value of t-statistic $(4,575)>$ T-table (1.96) and the p-value $(0.000)<0.05$ That is, the better Perceived Ease of Use consumer, then perceived Riskcustomers also will get better

The results of this study are supported by a study done Alalwa et al. (2016) showed that behavioral intentions (behavioral intention) is strongly influenced by the perceived usefulness, perceived ease of use, and perceived risk. Similarly, in the context of online shopping system, if the user thinks that the system is useful, then they are more likely to accept it. Therefore, according to TAM, it was hypothesized that Public Works will have a significant positive effect on the Adoption of e-commerce users. According to TAM, the direct effect of PEOU and PU explained by an increase PEOU, which results in improved performance by storing the effort required to do the same job.

\section{Pengaruh Perceived Ease of Use Against Behavioral Intention}

The fourth hypothesis presented earlier Perceived Ease of Use Against Perceived Risk Online Purchase Transaction TOKOPEDIA (Studies in Society PadangBased on the results of testing that has been done, hypothesis 4 is accepted. This is becausebecause the value of t-statistic (2599)> t-table $(1.96)$ and the p-value (0.005) $<0,05$ Artinya, the betterPerceived Ease of Use consumer, The Behavioral Intentionpelanggan will also be getting better

The results of this study are supported by a study done

Rauniar (2014) examined the behavior of individual adoption in using social networking site Facebook. Influence on the intention to use social networks based on perceived ease of use (EU), the user's critical mass (CM), a social networking site capability (CP), perceived playfulness (PP), trustworthiness (TW), and perceived usefulness (PU) tested from 398 users of Facebook were collected from a webbased questionnaire survey. The results show that social media TAM revised model proposed in this study support the hypothesis of all social media usage behavior. These results provide evidence for the importance of the key variables in addition to TAM in considering user engagement on social media sites and other business strategies related to social media to increase profits. Research conducted Jamshidi\&Hussin (2016) concluded that religiosity in the TAM model thereby increasing the 
intention to use. Meanwhile, perceived usefulness, perceived ease of use and attitude explains the low level of variance regarding the intention to use (intention to use), by adding perceived religiosity in the TAM model, this construction contributes to an increase in the variance.

\section{Pengaruh Against Perceived Usefulness Perceived Risk}

The hypothesis presented earlier 5 Perceived Risk Perceived Usefulness to the Purchase Online No TransakTOKOPEDIA (Studies in Society Padang) Based on the results of testing that has been done, Hypothesis 5 is accepted. This is becausebecause the value of t-statistic $(2,916)>$ T-table (1.96) and the p-value $(0,004)$ $<0.05$ That is, the better Perceived Usefulness consumers, The Perceived Risk customers also will get better

The results of this study are supported by a study done Mansour (2016) suggested that Perceived Usefulness influence positive messages on the Perceived Risk) Before reaching a purchase decision, consumers must go through several stages of Perceived Usefulness is defined as the extent to which a person believes that using a particular system would enhance or performance job. The main reason people exploit Tokopedia E-commerce systems is that they find useful system for their transactions (Sentosa et al., 2012).

\section{Pengaruh Perceived Usefulness Of Behavioral Intention}

The hypothesis presented earlier 6 Perceived Usefulness of the Behavioral Intention on Purchase Online Store Pedia (Studies in Society Padang) Berda sarkan the results of testing that has been done, hypothesis 7 is received. This is becausebecause the value of t-statistic (5084)> T-table (1.96) and the p-value $(0000)<0.05$ That is, the better Perceived Usefulness consumers, then behavioral Intention customers also will get better

The results of this study are supported by a study done Rauniar (2014) examined the behavior of individual adoption in using social networking site Facebook. Influence on the intention to use social networks based on perceived ease of use (EU), the user's critical mass (CM), a social networking site capability (CP), perceived playfulness (PP), trustworthiness (TW), and perceived usefulness (PU) tested from 398 users of Facebook were collected from a webbased questionnaire survey. The results show that social media TAM revised model proposed in this study support the hypothesis of all social media usage behavior. These results provide evidence for the importance of the key variables in addition to TAM in considering user engagement on social media sites and other business strategies related to social media to increase profits. Research conducted Jamshidi\&Hussin (2016) concluded that religiosity in the TAM model thereby increasing the intention to use. Meanwhile, perceived usefulness, perceived ease of use and attitude explains the low level of variance regarding the intention to use (intention to use), by adding perceived religiosity in the TAM model, this construction contributes to an increase in the variance.

\section{Pengaruh perceived Risk Against Behavioral Intention}

The hypothesis 7 presented earlier perceived RiskBehavioral Intention to Purchase Transaction Online Store Pedia (Studies in Society Padang) Berda sarkan the results of testing that has been done, hypothesis 7 is received. This is becausebecause the value of t-statistic (5.760)> t-table (1.96) and the $p$-value $(0000)<0.05$ That is, the better Perceived Risk consumers, then 
behavioral Intention customers also will get better

The results of this study are supported by research Koenig-Lewis et al. (2010), the perceived risk associated with the probability that something will happen and the consequences of the results are usually undesirable when it occurs. The vagueness of mobile banking services, the main features of the other services, causing hardship to the customers in the evaluation of the service prior to consumption. Thus, consumers tend to worry about security issues. For example, customers are concerned about the possibility that their money or personal information may be transferred to other parties without consent when transacting via $\mathrm{E}$ Commerce Technology (Hanafizadeh et al., 2014; Ramdhony\&Munien, 2013). IDT also incorporate the perceived risk as a factor affecting the use of new technologies.

\section{Self-efficacy influence Behavioral Intention To Purchase Transaction Online Tokopedia with Perceived Risk as mediation}

The hypothesis presented earlier 8 Self-efficacy Toward Behavioral Intention Online Store Purchase Transaction Pedia (Studies in Society Padang) Berda sarkan the results of testing that has been done, hypothesis 8 is received. This is because the Mediation Self- Efficacy against Intention Through Perceived Behavioral RiskVAF value $=21: 00 \%$ (partial mediation). That is, the better Mediation Self-Efficacy against Intention Through Perceived Behavioral Risk also will get better

The results of this study are supported by research Greogory (2011) defines Self Efficacy as confidence to know that their ability to perform some form of control over one's own benefit and events in the surrounding environment. According Ormrod (2008) Self-efficacy is the belief that one is capable of running a certain behavior to achieve certain goals. An important issue regarding the concept of selfefficacy and self-efficacy measurement was the specific nature, special accordance with the field situation, or particular circumstances. Research done by Alawan et al (2016) found that Self Efficacy is very influential and significant to Behavioral Intention,

Effect of Perceived Ease of Use Against Against Behavioral Intention to Perceived Risk as mediation

The hypothesis presented earlier

9 Perceived Ease of Use Against Against Behavioral Intention with Perceived Risk as mediation Online Store Purchase Transaction Pedia (Studies in Society Padang) Berda sarkan the results of testing that has been done, the hypothesis 9 is received. This is because MediationEase Of Use Through Behavioral Intention toward Perceived RiskVAF value $=80.9 \%$ Mediation Full (Full Mediation).That is, the better Mediation Ease Of Use of the Behavioral Intention Through Perceived Risk also will get better

The results of this study are supported by research Alalwa et al. (2016) showed that behavioral intentions (behavioral intention) is strongly influenced by the perceived usefulness, perceived ease of use, and perceived risk. Similarly, in the context of online shopping system, if the user thinks that the system is useful, then they are more likely to accept it. Therefore, according to TAM, it was hypothesized that Public Works will have a significant positive effect on the Adoption of e-commerce users. According to TAM, the direct effect of PEOU and PU explained by an increase PEOU, which results in improved performance by storing the effort required to do the same job.

Effect of Perceived Usefulness Against Against Behavioral Intention to Perceived Risk as mediation 
The hypothesis presented earlier 10 Against Against Perceived Usefulness Perceived Risk Behavioral Intention to mediationBased on the results of testing that has been done, the hypothesis 9 is received. This is because the Perceived Usefulness Against Against Behavioral Intention to Perceived Risk as mediationThat is, the better Mediation Perceived Usefulness of the Behavioral Intention Through Perceived Risk also will get better

The results of this study are supported by research conducted Alalwa et al. (2016) showed that behavioral intentions (behavioral intention) is strongly influenced by the perceived usefulness, perceived ease of use, and perceived risk. Similarly, in the context of online shopping system, if the user thinks that the system is useful, then they are more likely to accept it. Therefore, according to TAM, it was hypothesized that Public Works will have a significant positive effect on the Adoption of e-commerce users. According to TAM, the direct effect of PEOU and PU explained by an increase PEOU, which results in improved performance by storing the effort required to do the same job.

\section{CONCLUSIONS AND SUGGESTIONS}

Based on the results of this study concluded that:

1. Self-efficacyeffect on perceived RiskOnline Purchase Transaction Tokopedia (Studies in Society Padang)

2. Self-efficacy influence on behavioral IntentionOnline Purchase Transaction Tokopedia (Studies in Society Padang)

3. Perceived Ease Of Use effect on perceived RiskOnline Purchase Transaction Tokopedia (Studies in Society Padang)

4. Perceived Ease Of Use effect on behavioral IntentionOnline Purchase Transaction Tokopedia (Studies in Society Padang)
5. perceived Usefulnesseffect on perceived RiskOnline Purchase Transaction Tokopedia (Studies in Society Padang)

6. perceived Usefulnesseffect on behavioral IntentionOnline Purchase Transaction Tokopedia (Studies in Society Padang)

7. Perceived Risk Behavioral Intention affect the Online Purchase Transaction Tokopedia (Studies in Society Padang)

8. Self-efficacyeffect on behavioral Intention through Perceived Risk on customers Tokopediain the city of Padang. Perceived Risk partially mediate the relationship between self-efficacy and Behavioral Intention. This means that most of the effects of selfefficacy on Behavioral Intention mediated by Perceived Risk

9. Perceived Ease Of Use influence on Behavioral Intention via Perceived Risk on Tokopedia customers in Padang. Perceived Risk Full Mediation mediate the relationship between Perceived Ease Of Use and Behavioral Intention. This means that most of the effect of Perceived Ease Of Use of the Behavioral Intention mediated by Perceived Risk

10. perceived Usefulnesseffect on Behavioral Intention via Perceived Risk on Tokopedia customers in Padang. Perceived Risk partially mediate the relationship between Perceived Usefulness and Behavioral Intention. This means that most of the effect of the Behavioral Intention Usefulness 6Perceived mediated by Perceived Risk

As for suggestions that can give researchers for further research are as follows:

Berikut suggestions for improvements that can be given to the future based on the results of the research were 
obtained:

1. It is expected that in future studies to do sampling in other cities in West Sumatra who havebehavioral IntentionsSelfefficacy Intention To Purchase Transaction Online Tokopedia with Perceived Risk and Perceived Ease Of Use, Perceived Usefulness as a mediating variable with a larger sample.

2. PeThe next Scan can also use the respondents pelanggangon line from other companies that provide servicesEcomersSeuntil he could be a comparison study. Because of this current study is confined to the customers Purchase Online TokopedialnPadangsaja Urban Community.

3. PeThe next Scan can also add independent variables with other variables that affectbehavioral Intentionscustomers such as variable Marketing Mix. So it can see the influence of these variables on user interest and can be a consideration for employers in the development of future Tokopedia

\section{REFERENCE}

Adams, DA, Ryan Nelson., And Peter A. Todd. (1992). "Percieved usefulness, ease of use, and usage of information technology: A replication". MIS Quarterly, 16, 227-250.

Arwiedya, MochamadRidzky. (2011). Analysis of Effect of Price, Type Media Promotion, Risk Performance and Product Diversity Against Buying Decision Via Internet In Online Store. Semarang: Diponegoro University.
Anwar, Saifuddin. (2011). Scale

Preparation of Psychology.

Yogyakarta: Student Library

\section{Chao-Min Chiu et al. (2012). "Understanding customers' repeat purchase intentions inB2C e-commerce: the roles of utilitarian value, hedonic value andperceived risk". Information Systems Journal 24, 85-114.}

Chung Hoon, Park and Kim YoungGul.(2006). "The effect of information satisfaction and relational benefits on consumers' online shopping site commitments". Journal of Electronic Commerce in Organizations (4), 70-90.

Cooper, Donald R. and Pamela S. Schindler. (2006). Business Research Methods. Jakarta: PT. Global Media.

Dai Bo, Sandra Forsythe, and Wi-Suk Kwon. (2014). "The Impact of Online Shopping Experience on Risk Perceptions and Online Purchase Intentions: Does Matter Product Category?", Journal of Electronic Commerce Research, Vol 15 (1).

Davis, Fred D. (1989). "Perceived Usefulness, Perceived Ease of Use, and User Acceptance of Information Technology". MIS Quarterly Vol 13 (3): 319-340.

Elliot, S., \&Fowel, S. (2014). "Expectations vs. Reality: A Snapshot of Consumer experiences with Internet retailing". International Journal of Information Management, Vol 20: 323-336. Ferdinand, Augusty. (2006). Management Research Methods: Research 
Guidelines for Writing Theses and Dissertation Management Sciences. Semarang: Diponegoro University

Publishers Agency.

Forsythe, SM \& B. Shi. (2013). "Consumer Patronage and Risk Perceptions in Internet Shopping".Journal of Electronic Commerce Research.Vol 5 (3): 181-198.

Gauzente, C. (2004). "Web merchant's privacy and security statement: How reassuring are they customers? Two-sided approach ", Journal of Electronic Commerce Research. Vol 5 (3): 181-198.

Ghozali, Imam. (2011). Multivariate Analysis Applications With IBM SPSS Program 19. Ed. 5. Semarang: Diponegoro University Publishers Agency.

Gujarati, Damodar. (2003). Basic Econometrics: Sixth Edition. Jakarta: Erland.

Igbraria, M., A. Chakrabarti. (2000). "Computer Anxiety and Attitudes Towards Microcomputer Use". Behavior Inform. Tech. 9 (3) 229-241.

Jogiyanto.(2007).

Behavioral Information Systems. Yogyakarta: Andi Yogyakarta.

$\begin{array}{llr}\text { Kotler, } & \text { Philip and } & \text { Gary } \\ \text { Armstrong.(2016). } & \text { "Principles } \\ \text { of Marketing".10th Ed. New } \\ \text { Jersey: Pearson Prentice Hall. }\end{array}$

Laudon, Kenneth C., \&Laudon, Jane P. (2007).Management

Information Systems 10th Edition. Translation Christian Sungkono and MachmudinEka P. Jakarta: Four Salemba. Liao, Z., \& Cheung, MT (2001). "Internet-based e-shopping and consumer attitudes: An Empirical Study". Information Management, 38, 299-306.

Maholtra, NK, Kim, SS, \&Agarwal, J. (2004). 'Internet users' information privacy concern (IUIPC). The construct the scale, and a causal model ". Information Systems Research, 15 (4), 336-355.

Mowen, JC, \& Minor, M. (2012).Consumer behavior. Jakarta: Erland

Pavlou, PA (2010). "Consumer acceptance of electronic commerce: Integrating trust and risk with the technology acceptance model". International Journal of Electronic Commerce, Vol. 7 (3).

Peter, JP \& LX Tarpey. (1975) "A Comprehensive Analysis of Three Consumer Decision Strategies," Journal of Consumer Research, Vol. 2: 29-37.

Raman, Arasu., \&Viswanathan, A. (2011). "Web Services and eShopping Decisions: A Study on the Malaysian e-Consumer". IJCA Special Issue on: Wireless Information Networks \& Business Information System, hal.54-60.

Rofiq, Ainur. (2007). Effect of Dimensional Trust (Trust) Against E-Commerce 
Customer Participation (Study on Customer E-Commerce in Indonesia). Malang: Brawijaya University.

Sounders, Mark, Philip Lewis, and Adrian Thomhill.(2009). "Research Methods for Business Students". 5th Ed. London: Pearson Education.

Schiffman, Leon G., \& Leslie Lazar Kanuk. (2007). Consumer behavior. Jakarta: Index.

Schiffman, Leon G., Leslie Lazar Kanuk, and Vard H. Hansen. (2010). "Consumer Behavior". 2nd Ed. New Jersey: Pearson Prentice Hall.

Have now, Uma. (2006). Business Research Methods. Issue 4. Jakarta: Four Salemba.

Sugiyono.(2009). Business Research Methods (Quantitative Approach, Qualitative and R \& D). Bandung: Alfabeta.

Suhari, John. (2008). Buying Decisions Online and Factors Affecting. Semarang: Semarang Stikubank University.

Suhir, Imam Suyadi, and Riyadi. Moch. Influence of Risk Perception, Ease and Benefits of Online Purchase Decision. Malang: Brawijaya University.

Sunarto, Andi. (2009). Inside ECommerce. Yogyakarta: Garailmu.

Szymanski, DM, \&Hise, RT (2012). "ESatisfaction: An initial examination.Journal of Retailing". 76 (3).309-322.

Tjiptono, Fandy, Gregory Candra, and
Dadi Adriana.(2008), Strategic Marketing. Yogyakarta: Andi Offset.

Zikmund, William G., Barry J. Babin, Jon C. Carr, and Mitch Griffin. (2009). "Business Research Methods". 8th Ed. SouthWestern College Pub. 